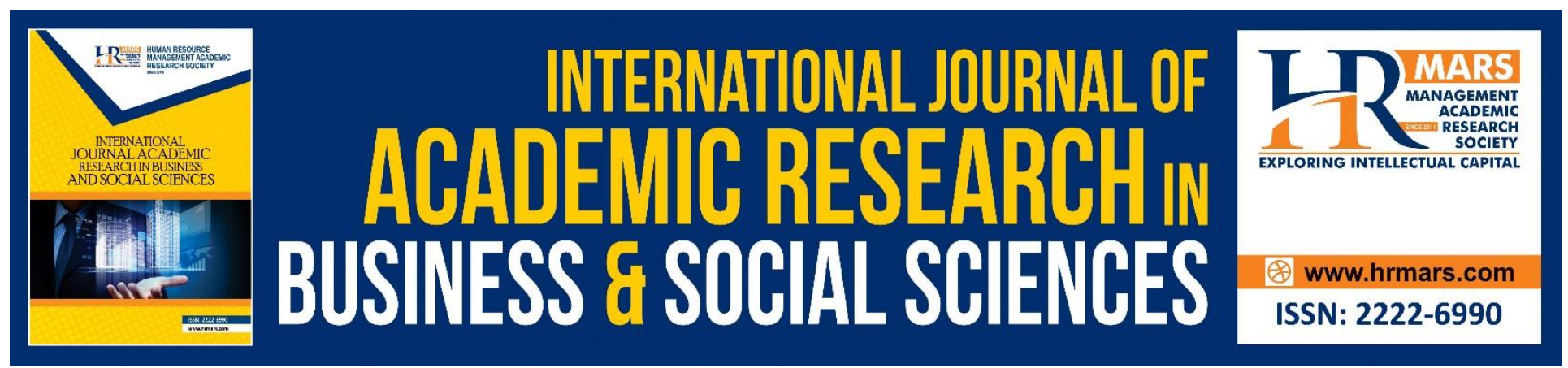

\title{
Is it Right to Blame Employers for not Hiring Persons with Disabilities?
}

\begin{abstract}
Abdul Razak Abd Manaf, Siti Zubaidah Othman, Zarina Mat Saad, Zakiyah Jamaluddin
\end{abstract}

To Link this Article: http://dx.doi.org/10.6007/IJARBSS/v9-i2/5508

DOI: $10.6007 /$ IJARBSS/v9-i2/5508

Received: 11 Jan 2019, Revised: 19 Feb 2019, Accepted: 26 Feb 2019

Published Online: 05 March 2019

In-Text Citation: (Manaf, Othman, Saad, \& Jamaluddin, 2019)

To Cite this Article: Manaf, A. R. A., Othman, S. Z., Saad, Z. M., \& Jamaluddin, Z. (2019). Is it Right to Blame Employers for not Hiring Persons with Disabilities? International Journal of Academic Research in Business and Social Sciences, 9(2), 1-9.

Copyright: (C) 2019 The Author(s)

Published by Human Resource Management Academic Research Society (www.hrmars.com)

This article is published under the Creative Commons Attribution (CC BY 4.0) license. Anyone may reproduce, distribute, translate and create derivative works of this article (for both commercial and non-commercial purposes), subject to full attribution to the original publication and authors. The full terms of this license may be seen

at: $\underline{\text { http://creativecommons.org/licences/by/4.0/legalcode }}$

\section{Vol. 9, No. 2, 2019, Pg. 1 - 9}

Full Terms \& Conditions of access and use can be found at http://hrmars.com/index.php/pages/detail/publication-ethics 


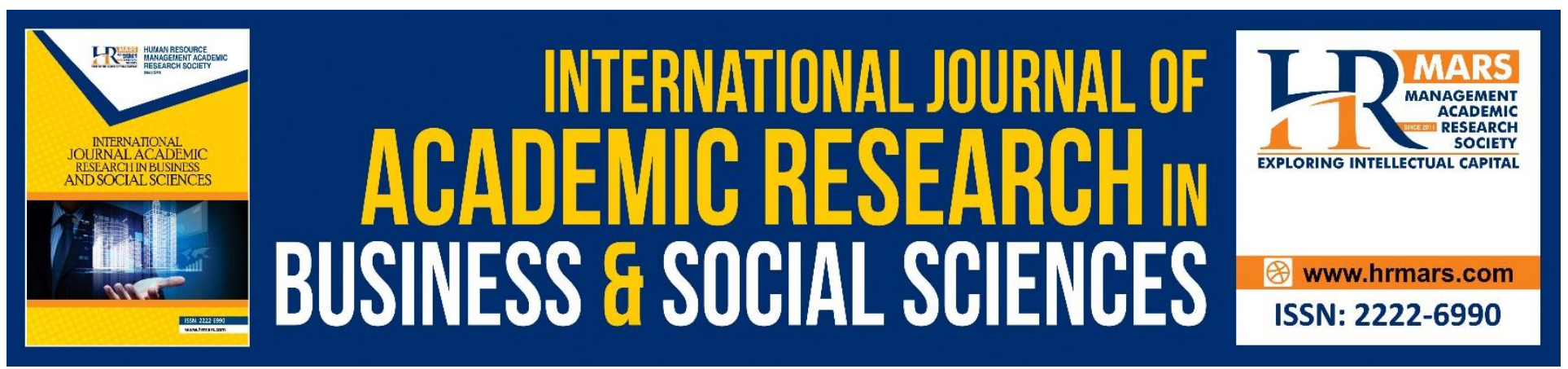

\title{
Is it Right to Blame Employers for not Hiring Persons with Disabilities?
}

\author{
Abdul Razak Abd Manaf1, Siti Zubaidah Othman², Zarina Mat Saad³, \\ Zakiyah Jamaluddin ${ }^{4}$ \\ ${ }^{13}{ }^{4}$ School of Applied Psychology, Social Work, and Policy \\ ${ }^{2}$ School of Business Management \\ Universiti Utara Malaysia, 06010 Sintok Kedah, Malaysia
}

\begin{abstract}
Many associate the low participation of persons with disabilities (PWDs) in the workforce with the employers' attitude towards PWDs. Employers are said failed to acknowledge the disabled population as the talent pool of skilled workers. However, little attention has been given to the issues and challenges that employers faced in hiring and managing PWDs. Therefore, the main objective of this study is to explore employers experience in hiring and managing PWDs at the workplace and issues that they faced. To uncover these issues, input from 19 employers were gathered through an on-site semi-structured interview. As cited by the employers, among the crucial issues employers faced in hiring PWDs include the difficulties to locate potential PWDs, PWDs lack of needed skills to perform task and employers' lack of communication skill to deal with PWDs. In terms of issues relating to managing PWDs at the workplace, the findings showed that PWDs who been hired need extra training in order to perform the given task. Apart from that, employers also shared that they are facing difficulties in dealing with PWDs negative attitude and mentality, communication problem, difficulties in handling PWDs, managing PWDs safety, matching work with PWDs ability, negative perception from co-workers and management and cost in managing PWDs. Based on the findings, several suggestions and recommendations were put forward to increase participation of PWDs in the workforce.
\end{abstract}

Keywords: Persons with Disabilities, Employer, Hiring, Managing, Malaysia

\section{Introduction}

It is acknowledged that some PWDs may not have the capabilities to work like able-bodied persons; nonetheless many are talented, able and prepared to work if given the opportunity. Serajul Haq (2003) stressed that employment symbolizes liberty and equal opportunity for PWDs. It is momentous as participation and access to employment is a fundamental right for them too. Serajul Haq added that employment for PWDs is significant for three major motives: (a) it signifies economic 
independence and solid source of income; (b) it represents a sense of self-esteem and self-respect; and (c) it indicates acceptance and integration into the mainstream of non-disabled community and acknowledgement of their contribution to the society. However, the number of PWDs who participated in the workforce is still low.

Reasons for the low participation of PWDs in the workforce have been put forward in the literature and these include barriers in the environment (access to education and transportation), barriers in the employment process (skill deficits, disability stigma and cost of accommodations) and attitudes of employers toward hiring PWDs contributed to some of the issues (Bruyere, 2000; Garske \& Stewart, 1999; Marrone \& Golowka, 1999; Khoo, Tiun \& Lee, 2013; Pratt, Gill, Barret \& Roberts; 1999; Roessler, 2002; Stacher \& Hendren, 1992; Tiun \& Khoo, 2013; Wright \& Multon, 1995). However, in most circumstances, when PWDs failed to get a job, employers will be the one to be blamed. In fact, many past studies have shown how employers be one of the contributing factors for the low participation of PWDs in the workplace. For example, studies conducted by Tiun and Khoo (2013) and Khoo, Tiun and Lee (2013) showed that most employers in general were unfamiliar with and insensitive to the needs of their employees with disability. They further found that the built environments in the workplace were not disability-friendly which hindered the movements of employees with disability.

In the past, most of the studies have focused on the negative attitude of employers that limit the employment opportunity among PWDs as many believed that employers' attitude towards PWDs will determine employment opportunity among PWDs. However, the real reasons why employers are reluctant to hire PWDs are still not widely been discussed in the literature. Therefore, this paper reports findings on the issues and challenges that employers faced in hiring and managing PWDs at the workplace in the Malaysian context.

\section{Literature Review \\ Employment and PWDs}

Reviewing past literature has shown that employers' attitude towards PWDs will determine employment opportunity among PWDs. Employer' attitudes are crucial because of their presumed relationship with hiring behavior. Attitudes are negative or positive assessments that portray a predisposition to behave in a respectable way (McDonnall, Crudden, \& O'Mally, 2015). Attitudes are more likely to anticipate behavior when they are more specific (rather than global), strong, accessible over time (Fishbein \& Ajzen, 1975). For instance, assessing the attitudes of employer on the ability of the employees with a visual disability to work in the employers' organization is desirable to assessing employers' general attitudes towards blinds or visually impaired people. Negative attitudes towards disabled employees have been connected with discrimination in hiring, training, promotion, placement, harassment and relationships with coworkers (Hernandez, Keys, \& Balcazar, 2000; McDonnall et al., 2015). Negative employer attitudes have long been regarded main barrier to employment for people with disabilities (Crudden, Williams, McBroom, \& Moore, 2002). This is often considered as the greatest challenge to employment for this population by both rehabilitation professionals and people with disabilities. 
Across employers of all sizes, it is significant to comprehend what other common views on hiring disabled people present and how such views arise. There have been several struggles to explore such attitudes of employer within the hospitality and leisure industry. Some employers, especially in leisure and hospitality industries where employees directly and frequently interact with customers, tend not to employ people with disabilities, because, they perceive them, make business less attractive in the eyes of customers (Colella \& Bruye're, 2011). The evidence of negative attitudes of employers towards people with disabilities is indicated in the study conducted by Groschl (2005) in the Canadian hotel industry. The findings showed that some employers have discriminatory and negative beliefs on employing people with disabilities. In addition, research has portrayed that employers share anxieties about the capability of disable people to execute necessary job functions. This notion is also supported by Bruyère, Erickson, \& Vanlooy (2006) that lack of knowledge or skills as a main concern for employers in employing disabled people. However, a study which was conducted to 500 employers of foodservices indicated that having formerly employed disabled people vastly improve attitudes of employers towards such employees (Chi \& Qu, 2003). Because of attitudes of employers are normally among the most tough to change barriers to employing disabled people (Bruyère et al., 2006), it is crucial to comprehend the extent of and foundation for these beliefs.

Although employers' negative attitudes and concerns available for some businesses, the study has portrayed the benefits of developing a friendly culture for people with disabilities. In their restaurant industry analysis, Slonaker, Wendt, and Baker (200, p 57), discovered that some employers tend to incorporate diversity as "an essential component in the way [they] do business." A wider survey of employers by the federal Job Accommodation Network portrayed that employers who employed disabled people were capable to obtain qualified employees, excel profits, and obtaining from significant training costs (Hartnett, Stuart, Thurman, Loy, \& Batiste, 2011). Lengnick-Hall (2007) asserts that employees with disabilities can truly diminish business costs if employers establish a friendly environment for disabled people by reducing turnover costs, lessening litigation likelihood, and acquisition government tax breaks. In interviews that conducted to managers of leisure and hospitality industries also support the assertion that employees with disabilities depicted lower rates of absenteeism than non-disabled employees. Interviews that conducted to managers of leisure and hospitality industries also support the assertion that employees with disabilities depicted lower rates of absenteeism than nondisabled employees(Jasper \& Waldhart, 2013).

Supported employment to people with disabilities has a significant role to play. Such an important scheme helps people, particularly with disabilities, to work together with non-disabled employees successfully. It can have a broader impact on employers' attitudes, employees, society in general. Some members of the states have a successful practice of this form of employment. In Sweden, very harshly people with disabilities acquire basic support from the sponsor in looking for a job (CommissionStaff, 1998). The responsibilities of the support individual include setting out job aspirants' qualifications and wishes, finding appropriate proposals for workplace to help then 
being provided with commitments and workplace training these proceedings are basically intended at the psychological and intellectually people with disabilities. The individualized management case, tail created approach is essential in letting people with disabilities to secure appropriate jobs.

\section{Reasons why Employers are not Employing PWDs}

In the literature, there are various reasons been put forwards why employer are reluctant to hire PWDs. Though employers rarely admit the real reasons that keep them from hiring PWDs, Peck and Kirkbride (2001) argued that their primary reason is due to fear. In their article, they have highlighted four kind of fears that employers face. The first fear is fear of the cost associated with hiring. Many employers believed that they need to spend lots of money if they were to hire PWDs such as providing them with accommodation, facilities and renovation to accommodate the disabled. Second, is the fear of additional supervision and loss of productivity. Employers are concerned about the need to give special attention to PWDs at the workplace. In other words, they are concerned with the amount of time the supervisor would need to commit to the disabled employees. Apart from that, they are also concerned about the productivity of the disabled employees and often perceived that they have to come out with two different productivity standards. The third fear is fear of being stuck forever. Many employers have the general feelings that PWDs are protected class who cannot be terminated if they failed to perform the essential functions of the job. Finally, is the fear of damaged good. Employers do not want to be seen as doing charity when hiring PWDs but would like to be seen as the right thing to do.

In a study conducted by Kaye, Jans and Jones (2011) on human resources professionals and managers working at ADA - recalcitrant organizations who attended ADA or other disability-related trainings provided by DBTAC-Pacific ADA Center its affiliates, found that the three highest reasons why employers might not hire PWDs are related to cost of accommodations, lack of awareness as to how to deal with workers with disabilities and their accommodation needs and fear of being stuck with a worker who cannot be disciplined or fired because of the possibility of lawsuit. In their study also, they found that $70 \%$ of the respondents indicate reasons such as difficulty in assessing an applicant's ability to perform job, concerns over extra supervisory time, other cost worries, concern that PWDs won't perform as well as persons without disability employees and lack of job applicants with disabilities for not hiring PWDs.

In one practitioner writing, Gordon (2018) has highlighted several reasons why employers are reluctant to hire PWDs. Among the reasons given by employers include not having the accommodation, they requires applicant with specific expertise, requires extensive job modifications, too risky to hire PWDs, only hiring for specific disabilities and hiring PWDs did not give any business benefits. 


\section{Methodology \\ Research design}

In this study, an on-site semi-structured interviews and survey were utilized as the data collection method to uncover participants' perspectives on the PWDs employment issues. Respondents were asked to elaborate on their experiences and perceptions in relations to hiring and managing PWDs at the workplace. Thus, interviews allowed for flexibility and openness. Questions were exploratory and discovery-oriented (Strauss \& Corbin, 1998); thus, allowing the participants to express issues of PWDs at the workplace within their own frame of references. The one-to-one interview and survey lasted for an average of one hour. All responses were transcribed and scrutinized very closely and the themes were quantify into frequency and percentage to facilitate interpretation.

\section{Participants}

A total of 19 employers (8 males, 11 females) from one state in Peninsular Malaysia has participated in this study. All these 19 employers have an experience in hiring and managing PWDs. On average, the participants are 37 years old with most of them (10) are married. Majority of the participants (13) are Malay and Muslim. Most of the participants (6) are a diploma or a degree holder. Majority of the respondents (12) have been working with the organization between 1 to 10 years. Most of the participants (6) are managers.

\section{Results and Discussions}

During the interview, employers were asked to share their experiences in hiring and managing PWDs at the workplace. These include the challenges that they faced. Out of 19 employers interviewed, 17 of them shared their experiences with seven of them claimed that they did not face any issues with their disabled employees. In general, employers are willing to hire PWDs as they feel that PWDs also need to be given equal chance for employment. It was encouraging to note that even though majority of the respondents did not have any experience in hiring PWDs, they took the initiative to create jobs for PWDs. Thus, the government should acknowledge and support these initiatives and efforts by providing them with various assistance and incentives.

Even though employers are willing to hire PWDs, they also have acknowledged that they faced some challenges in hiring PWDs. From 10 employers, 6 of them shared the difficulties to locate good potential PWDs. In other words, they didn't have the knowledge on how or where to find them. The current practice is they hire PWDs through walk-in interview. Issue of PWDs working experiences is also being discussed by the employers. Three employers shared that most of the PWDs who came for employment do not have prior working experience or working exposure. This may due to the parents being too protective of their disabled child. Communication skill is another issue that employer shared during the interview especially when handling job interview with persons with hearing impairment. Since the employer doesn't know sign language, the interview became a problem. 
INTERNATIONAL JOURNAL OF ACADEMIC RESEARCH IN BUSINESS AND SOCIAL SCIENCES

Vol. 9, No. 2, Feb, 2019, E-ISSN: $2222-6990$ ๑ 2019 HRMARS

Table 1. Issues in hiring PWDs at the workplace

\begin{tabular}{clcc}
\hline Num & \multicolumn{1}{c}{ Responses } & Frequency & Percentage \\
\hline 1 & $\begin{array}{l}\text { Employers lack of access to locate } \\
\text { potential PWDs }\end{array}$ & 6 & 60 \\
2 & $\begin{array}{l}\text { PWDs lack of work exposure / } \\
\text { experiences }\end{array}$ & 3 & 30 \\
3 & $\begin{array}{l}\text { Employers lack of communication skill } \\
\text { when dealing PWDs }\end{array}$ & 1 & 10 \\
\hline
\end{tabular}

Apart from that, employers were also asked to share their experience in managing disabled employees at their workplace. Eight employers shared that PWDs that they hired lack of skill needed to perform the given task. Thus, extra training is needed. Other issues that were also reported during the interview include PWDs' negative attitude and mentality, communication problem especially when dealing with employees with hearing impairment, difficulties in handling PWDs, safety issues relating to PWDs, matching work with PWDs ability, negative perception from co-workers and management and cost in managing PWDs.

Table 2. Issues in managing PWDs at the workplace

\begin{tabular}{clcc}
\hline Num & \multicolumn{1}{c}{ Responses } & Frequency & Percentage \\
\hline 1 & $\begin{array}{l}\text { Extra training needed to perform the } \\
\text { given task }\end{array}$ & 8 & 80 \\
2 & $\begin{array}{l}\text { Negative attitude and mentality of } \\
\text { PWDs }\end{array}$ & 7 & 70 \\
3 & Communication problem & 4 & 40 \\
4 & Difficulties in handling PWDs & 3 & 30 \\
5 & Managing PWDs safety & 2 & 20 \\
6 & Matching work with PWDs ability & 2 & 20 \\
7 & Negative perception from co-workers & 2 & 20 \\
& and management & 1 & 10 \\
\hline
\end{tabular}

\section{Conclusions and Recommendations}

In summary, the present findings indicate that several parties, including the government, employers and PWDs themselves need to take initiatives in improving the participation of PWDs in the workforce. In regards to this, the government needs to provide an on-going support for both PWDs and employers such as improving the function of Jobs Malaysia and designing other development programs. Strategic planning and interventions to provide potential talented PWDs for employers and organizations to locate are crucial in order to better provide participations of PWDs in the job market. It is also critical for the government and other community efforts to establish more training centers to accommodate PWDs according to their disabilities, revise existing training curriculum to meet industry needs and appoint a certification body to certify and monitor training programs offered. At the same time, PWDs themselves need to be given the opportunity to equip themselves 
with the right skills and knowledge that make them ready to work. They need to be given equal opportunity and access to education and training as well.

In short, it is considered to be unfair to blame the employer solely for not employing PWDs when they are not been trained and given the knowledge on how to manage PWDs. In this context, few suggestions could be critically implemented. Among others, the role of job coach needs to be revised and improvised to intensify participation of PWDs in the workforce, efforts to train and develop more in-house job-coach in organization, initiatives to provide more attractive incentives and benefits for organization participating in job-coach programs and endeavors to offer resource guide for employers in recruiting, hiring, retaining and promoting persons with disabilities. Given these recommendations being executed, involvement of more PWDs in the job market could be positively and successfully engaged.

\section{Acknowledgement}

We would like to express our heartfelt gratitude and deepest appreciation to Darul Ta'zim Family Development Foundation, under the state of Johor for awarding the research grant to undertake this study.

\section{Corresponding Author}

Abdul Razak Abd Manaf, Ph.D

School of Applied Psychology, Social Work, and Policy

Universiti Utara Malaysia, 06010, Sintok Kedah

Malaysia

Email:a.razak@uum.edu.my

\section{References}

Bruyere, S.M. (2000). Statistics about people with disabilities and employment. Retrieved August 5 2013, from http://www.dol.gov/odep/pubs/ek01/stats.htm

Garske, G.G., \& Stewart, J.R. (1999). Stigmatic and mythical thinking: Barriers to vocational rehabilitation services for persons with severe mental illness. Journal of Rehabilitation, 65(4), 4-8.

Gordon, C. (2018). Why don't employers hire people with disabilities? Retrieved from https://risepeople.com/blog/why-dont-employers-hire-people-with-disabilities/

Kaye, H. S., Jans, L.H., \& Jones, E. C. (2011). Why don't employers hire and retain workers with disabilities? Journal of Occupational Rehabilitation, 21(4), 526-536.

Khoo, S. L., Tiun, L. T., \& Lee, L. W. (2013). Unseen challenges, unheard voices, unspoken desires: Experiences of employment by Malaysians with physical disabilities. Kajian Malaysia, 31(1), 37-55.

Lengnick-Hall, M. L. (2007). Hidden talent: How leading companies hire, retain, and benefit from people. Westpot Connecticut: Praeger Publisher.

Marrone, J., \& Golowka, E. (1999). If work makes people sick, what do unemployment, poverty and social isolation cause? Psychiatric Rehabilitation Journal, 23(2), 187-193. 
Peck, B., \& Kirkbride, L. T. (2001). Why businesses don't employ people with disabilities. Journal of Vocational Rehabilitation, 16(2), 71-75.

Pratt, C. W., Gill, K. J., Barret, N. M., \& Roberts, M. M. (1999). Psychiatric rehabilitation. San Diego, CA: Academic Press

Roessler, R. (2002). Improving job tenure outcomes for people with disabilities: The 3M model. Rehabilitation Counseling Bulletin, 45(4), 207-212.

Serajul Haq, F. (2003). Career and employment opportunities for women. Asia Pacific Disability Rehabilitation Journal, 14(1), 71-78.

Stacher, J., \& Hendren, G.R. (1992). Employer agreement with the Americans with Disabilities Act of 1990: Implications for rehabilitation counselling. Journal of Rehabilitation, 58(3), 13-17.

Tiun, L. T., \& Khoo, S. L. (2013). Challenges faced by Malaysians with disabilities in the world of employment. Disability, CBR \& Inclusive Development, 24(1), 6-21.

Wright, G. E., \& Multon, K. D. (1995). Employers' perceptions of nonverbal communication in job interviews for persons with physical disabilities. Journal of Vocational Behavior, 47, 214-227. 